\title{
A case study of impacts of wetland area on flood index characteristics and channel morphology in southern Quebec (Canada)
}

\author{
Ali A. Assani ( $\square$ ali.assani@uqtr.ca ) \\ L'Université du Québec à Trois-Rivières https://orcid.org/0000-0002-9550-2251
}

\section{Research Article}

Keywords: Floods, magnitude, duration-frequency, bankfull width, sinuosity, Canadian Shield, Quebec

Posted Date: October 25th, 2021

DOl: https://doi.org/10.21203/rs.3.rs-978156/v1

License: (c) (i) This work is licensed under a Creative Commons Attribution 4.0 International License.

Read Full License 


\section{Abstract}

Two characteristics (magnitude and duration-frequency) of two indices of high (Qmax, annual flooding) and low intensities (Q90) floods and the morphology (bankfull width and sinuosity) of channels were compared for the Matawin $\left(1,390 \mathrm{~km}^{2}\right)$ and Petite Nation $\left(1,330 \mathrm{~km}^{2}\right)$ rivers on the Canadian Shield, which are differentiated mainly by wetland and forest areas. Wetlands cover $9 \%$ and $15 \%$ respectively in the Matawin and Petite Nation watersheds. This comparison revealed that the magnitude of high floods (Qmax) in the Matawin River was on average about twice the magnitude of high floods in the Petite Nation River from 1945-2019. No significant difference was observed in the magnitude of low floods (Q90) between the two rivers. As for the duration-frequency of heavy floods (Qmax), it was, on average, about three times higher in the Petite Nation River watershed than in the Matawin River watershed. The opposite is true for low floods (Q90). Morphologically, this difference in the magnitude and durationfrequency of heavy floods is seen in the bankfull width and sinuosity between the channels of the two rivers. The Matawin River channel is narrower and more sinuous than the Petite Nation River channel. This study is the first to demonstrate the impact of wetlands on channel morphology for Canadian Shield rivers in southern Quebec.

\section{Introduction}

Flooding and channel morphology are the result of many factors. Land use is considered one of the major factors in flood genesis and, consequently, in the morphological evolution of river channels. Much work has already been devoted to the impacts of land use on river floods (e.g., Acreman and Holden, 2013; Archer, 2003; Bandyopadhyay and De, 2018; Blöschl et al., 2007; Brandolin, Avalos, \& De Angelo, 2013; Bronstert, Niehoff, \& Bürger, 2002; Brown et al., 2005; Bullock and Acreman, 2003; Buytaert et al., 2004; Caissie et al., 2002; Cooper et al., 2013; Fashae and Olusola, 2017; Lane et al., 2005; Li et al., 2007; Nabegu, 2014; O'Connell et al., 2007; Ott and Uhlenbrook, 2004; Petersen et al, 2017; Pfister et al., 2004; Poff et al, 2006; Robinson and Dupeyrat, 2005; van Roosmalen et al., 2009; Shepherd et al., 2010; Storck et al., 1998; Tan and Gan, 2015; Wang and Hejazi, 2011; Zhang et al., 2018). Several studies have studied the impacts of land use on the morphological evolution of channels (e.g., Clark and Wilcock, 2000; Gordon and Meetemeyer, 2006; Kasai, 2006; Lu, 2005; Towsend et al., 2004; Vanacker et al., 2005; Yan et al., 2019; Zeiger and Hubbart, 2019). However, the latest studies focus mainly on deforestation, urbanization and agriculture. No study has yet examined the impacts of wetlands on channel morphological evolution. However, much work has already been devoted to the hydrological impacts of these wetlands. In their almost exhaustive summaries, Bullock and Acreman (2003) as well as Acreman and Holden (2013) have shown that these hydrological impacts induced by wetlands can vary from one watershed to another depending on several following factors: landscape location and configuration, soil characteristics, topography, soil moisture status, etc. Morphological, these conclusions suggest that wetlands can induce different morphological impacts. It therefore becomes extremely important to determine the impacts induced by wetlands on the morphological evolution of the river channels according to the hydrological changes they induce. This problem has never been analyzed in the 
scientific literature to our knowledge, particularly in Southern Quebec. It is therefore imperative to fill this gap with regard to Quebec, because for two last decades, like many regions in the world, this province of Canada has been facing several catastrophic floods which have causes extensive and expensive material damages. These floods are obviously attributed to climate change. One of the solution mentioned in public opinion is the restoration of wetlands, the area of which has significantly decreased over time in Quebec due to the intensive development of agriculture and urbanization. To validate this thesis, it is therefore important to determine the impacts of these wetlands on the high and low intensities flood flows and, by incidence, on the morphological evolution of the river channels.

In Quebec, several studies have already been done on the impacts of agriculture on river flows (e.g., Assani et al., 2016; Hadeland et al., 2007; Lavigne et al., 2014; Muma et al., 2011, Muma et al., 2016; Quilbé et al., 2008; Sylvain et al., 2015). Others have examined the impacts of wetlands on the hydrology of small headwaters basins (e.g., Branfireun and Roulet, 1998; Devito et al., 1996; Fraser et al., 2001; Quinton and Roulet, 1998; Roulet, 1990a, 1990b, 1991; Roulet and Woo, 1986). However, no study yet exists that examines how these wetlands impact channel morphology in relation to flood characteristics. To fill this gap, this study will compare the annual flood characteristics and morphology (bankfull width and sinuosity) of two watersheds, which differ mainly in wetland area, in southern Quebec. The purpose of this study is to determine whether wetlands can mitigate or amplify the intensity and/or duration of high and low flood flows and their impacts on channel morphology.

\section{Methodology}

\subsection{Selection of watersheds studied and description}

We compared the Petite Nation River to the Matawin River for the following reasons, to analyze the influence of wetlands on flood indices and the morphology of the Petite Nation River channel:

- The watersheds of the two rivers have very similar physiographic and hydroclimatic characteristics due to their spatial proximity. In fact, both watersheds lie entirely on the Canadian Shield.

- Despite this similarity in physiographic and hydroclimatic characteristics, the two watersheds differ mainly in forest and wetland area (swamps, marshes, bogs, lakes, etc.). This makes it possible to determine the influence of wetlands on the hydrology and morphology of the Petite Nation River channel, using the Matawin River as a reference.

- In both watersheds, flows have been measured continuously for more than 80 years. This makes it possible to compare their hydrological behaviour in wet and dry periods.

- Finally, the Matawin River watershed, which serves as a reference watershed, is also one of the reference watersheds for monitoring the impact of climate change on river flows across Canada.

The physiographic and climatic characteristics of both watersheds are presented in Table 1 and their locations are indicated in Figure 1. The data on physiographic characteristics (area, average slope, forest and wetland percentages) and climatic characteristics (total precipitation, average annual temperatures) 
presented in Table 1 were obtained from Belzile et al. (1997) and the Organisme du bassins versants des rivières Rouge, Petite Nation et Saumon's report. Climate data were obtained from the Environment Canada website (https://climat.meteo.gc.ca/climate_normals/index_f.html, accessed 2020-05-09).

Table 1

Comparison of the physiographic and climatic characteristics of the two river watersheds.

\begin{tabular}{|lll|}
\hline Variables & Matawin River & Petite Nation River \\
\hline Physiographic data & & \\
\hline Drainage Area $\left(\mathrm{km}^{2}\right)$ & 1390 & 1330 \\
\hline Mean slope $(\mathrm{m} / \mathrm{km})$ & 1.25 & 1.24 \\
\hline Drainage density $\left(\mathrm{km} / \mathrm{km}^{2}\right)$ & 0.46 & 0.43 \\
\hline Forests surface area $(\%)$ & 90 & 83 \\
\hline Wetlands surface area $(\%)$ & 9 & 15 \\
\hline Agricultural surface area $(\%)$ & 0 & 0.6 \\
\hline Urbanized surface area $(\%)$ & 0 & 0 \\
\hline Climatic data* & & \\
\hline Climate station & Saint-Michel-Des-Saints & Nominingue \\
& $\left(46^{\circ} 41^{\prime} \mathrm{N}, 73^{\circ} 55^{\prime} \mathrm{W}\right.$, & $\left(46^{\circ} 24^{\prime} \mathrm{N}, 75^{\circ} 05^{\prime} \mathrm{W}\right.$, \\
\hline Annual mean daily Temperature $\left({ }^{\circ} \mathrm{C}\right)$ & $351 \mathrm{~m})$ & $274 \mathrm{~m})$ \\
\hline $\begin{array}{l}\text { Annual mean daily maximum Temperature } \\
\left({ }^{\circ} \mathrm{C}\right)\end{array}$ & 2.7 & 3.0 \\
\hline $\begin{array}{l}\text { Annual mean daily minimum Temperature } \\
\left({ }^{\circ} \mathrm{C}\right)\end{array}$ & 8.9 & 9 \\
\hline Annual total precipitation $(\mathrm{mm})$ & -3.5 & -3 \\
\hline Annual total rainfall $(\mathrm{mm})$ & 877.6 & 1083.8 \\
\hline Annual total snowfall $(\mathrm{cm})$ & 720.1 & 833.1 \\
\hline * = climate normals during $1971-2000$ period. & 157.6 & 251.3 \\
\hline
\end{tabular}

The two spatially contiguous watersheds lie entirely on the Canadian Shield, on the north (left) shore of the St. Lawrence River. In both watersheds, the Canadian Shield (Grenville Province) consists mainly of metamorphic rock (gneiss). Basic and sedimentary rocks can also be observed. When these rocks are not flush with the surface, they are covered by surficial deposits of glaciofluvial and maritime origin (gravel, sand, till, etc.). The morphology of the channels of these two rivers is characterized by a quasi-regular succession of large, sinuous reaches with low slopes in surficial deposits and narrow, substraight reaches 
with high slopes in rocky outcrop areas. The forest massif consists mainly of sugar maple (Acer saccharum) (sugar maple-yellow birch forest and basswood-sugar maple forest). The climate is temperate-continental, characterized by warm summers and cold winters. The Petite Nation River flows from north to south into the Ottawa River. In contrast, the Matawin River flows from west to east and flows, as the main tributary, into the Saint-Maurice River. The Mont-Tremblant massif separates their watersheds (Figure 1). The two watersheds are very sparsely inhabited upstream of flow gauging stations. There are no agricultural activities. The only human activity is limited to logging, the main activity in both watersheds. Daily flow data were extracted from the website of the Ministère d'Environnement et de Lutte contre les changements climatiques' Centre d'expertise hydrique du Québec (https://www.cehq.gouv.qc.ca/, accessed on 2020-02-2020). It is important to note that the absence of human activities in both watersheds did not change runoff conditions over time. Table 1 shows that forest area is smaller in the Petite Nation River watershed (83\%) than in the Matawin River watershed $(90 \%)$ due to logging. In contrast, wetland areas (lakes, marshes, swamps, bogs, etc.) are larger in the Petite Nation River watershed (15\%) than in the Matawin River watershed (9\%). Ultimately, the two watersheds constitute life-sized experimental watersheds to differentiate the respective influence of deforestation and wetlands on flood index characteristics and channel morphology in southern Quebec.

\subsection{Definition of flood index characteristics and statistical data analysis}

Morphological evolution depends mainly on flood evolution. To determine the influence of wetland area on channel morphology in both rivers, the flood characteristics of magnitude and duration were compared. In terms of magnitude, four hydrological series of two flood indices were defined. The first hydrological series consisted of maximum flow values (Qmax) measured each year from 1945-2019. This series represents heavy (high) floods, that is, floods whose flows reached or exceeded annual flooding. The last hydrological series consisted of flow values corresponding to the 90th percentile (Q90) calculated each year based on daily flows over the same period (1945-2019). These flood flows were below the minimum flow of annual flooding. They included all medium and low floods whose peaks did not reach the lowest annual flood (annual daily maximum flow, Qmax) observed since 1945. From a morphological point of view, these two flood indices include all flood flows of low to high intensity that can cause morphological changes (bank and bed erosion, sediment transport, etc.). In each of these two series, the mean daily flow values (average magnitude), as well as the highest (maximum magnitude) and lowest (minimum magnitude) daily flow values were calculated. In terms of flood duration-frequency, the minimum value (the lowest flow) for each of the two indices (Qmax and Q90) were first considered. The total number of days during which this minimum value flow (minimum threshold) was reached or exceeded in a year during the period from 1945-2019 was then calculated. Two other hydrological series of daily flow duration-frequency (in days) were also established, each corresponding to a flow magnitude series: DQmax and DQ90. For these hydrological flow duration-frequency series, the mean flow duration value, as well as the highest (maximum duration-frequency) and lowest (minimum duration-frequency) mean values were calculated. It is important to note that the duration-frequency of Q90 was calculated by subtracting the total number of days during which the lowest (minimum) flow corresponding to the 90th 
percentile flow series (Q90) during the period 1945-2019 was reached or exceeded from the total number of days that the lowest (minimum) flow from the annual flooding series (Qmax) during the same period was reached or exceeded.

Statistically, the means of these four hydrological series of both rivers were compared using statistical parametric (one-way ANOVA) and non-parametric (Kruskal-Wallis) tests. Because of the small difference in the size of the two watersheds, flows measured in $\mathrm{m}^{3} / \mathrm{s}$ were converted to specific flows (ratio of flows to watershed area multiplied by 1,000 ) expressed in $\mathrm{L} / \mathrm{s} / \mathrm{km}^{2}$ in order to compare flood index flow values.

\subsection{Channel morphology and sedimentology analysis}

To analyze the influence of wetlands on the morphology of the two channels, bankfull width and sinuosity were measured. The method used is described in detail in our previous work (e.g., Aubry et al., 2013; Vadnais et al., 2012). The first step of the mapping analysis was to map the banks for the two rivers under study over a maximum distance of $10 \mathrm{~km}$ (as the crow flies from the flow gauging station). This distance was largely sufficient to compare the mean bankfull width and sinuosity of the two rivers, since the surface area of the two watersheds upstream of the gauging stations was almost identical. To map the banks, aerial photographs from the Inventaire écoforestier du Québec méridional (produced between 2002 and 2017) were used with ArcGIS software. These images were provided by the Ministère des Forêts, de la Faune et des Parcs (MFFP). The resolution is $30 \mathrm{~cm}$ and planimetric accuracy is $2 \mathrm{~m}$. Classes of linear entities (polylines) were created using photointerpretation to accurately map the upper limit of the channels where there is a break in the vegetation and the mark left by the highest natural waters on each side of the shoreline (bankfull).

After vectorizing the shorelines, a central centreline corresponding to the watercourse channel was generated using the "TIN" function in Esri's ArcGIS software. This function made it possible to create a linear interpolation between the channel boundary vectors, assigning an equal distance value to them. In our case, values of 1 and 3 were assigned to each of the banks (left and right) and subsequently, a line was produced at the median (value of 2) of the interpolation between the banks using the "Contour" function. After the aerial photographs were processed, the river banks were digitized (at bankfull level as defined by the vegetation edge) using the ArcMap tools from the ArcGIS software. To limit error on the bank outline, a three-dimensional digital stereoscope was used, as this allows for three-dimensional viewing of the channel. Channel width was measured by automatically drawing straight lines perpendicular to the channel using an ArcGIS extension developed at the Laboratoire Interdisciplinaire d'application en géomatique environnementale (LIAGE) and integrated into ArcGIS. This automated approach eliminated all human error associated with the perpendicular lines and thus with measuring the bankfull width of the channel. The software also allowed for automated drawing of perpendicular lines at the same location between two points separated by the same distance on aerial photos taken at different times, something that is very difficult to do manually. Once the banks were delineated, the perpendicular lines were drawn by first finding the midpoint of each cross-section (between the two banks), then drawing the centerline joining all midpoints, and finally drawing lines perpendicular to this centreline at all midpoints. Over 250 measurements (according to the total 10-km length of the analyzed section) of the 
channel bankfull width were thus done with the software at spacing of approximately $50 \mathrm{~m}$. Due to differences in sinuosity between the two rivers, the number of bankfull width measurements was higher for the Matawin River (more sinuous channel) than for the Petite Nation River. Ground observations were used to validate the channel shore delineation done with aerial photography. The channel shore limits used to calculate the channel bankfull width were defined fairly accurately with this technique. Several field visits were done to test the validity of bank delineation from aerial photographs against field measurements. To determine the maximum error on bankfull width measurements from photo interpretation, air photo interpretation (measurement of width from aerial photos) was carried out by two independent operators. The maximum difference in bankfull mean width at a given station between the values obtained by the two operators was $<1 \mathrm{~m}$. This maximum difference was therefore deemed to represent the maximum error on channel width measurements from photo interpretation at a given station. Mean bankfull width values for the two rivers were compared using the Kruskal-Wallis nonparametric and ANOVA parametric tests. Similar to flows, because of the difference in the size of two watersheds, the bankfull width measured in meters for the channels was changed to a specific width (ratio between the bankfull width and the watershed area) at bankfull expressed in $\mathrm{mm} / \mathrm{km}^{2}$. This change is explained by the fact that the width of a river channel increases proportionally to the surface area of its watershed, as demonstrated by numerous studies on hydraulic geometry theory (e.g., Ferguson, 1986). To calculate sinuosity, we calculated the ratio of the real total channel length over a distance of $10 \mathrm{~km}$ (including meanders) to the length of the channel as the crow flies over the same distance of $10 \mathrm{~km}$ (ignoring meanders).

With respect to sedimentological data, for the Matawin River, 15 sediment samples were collected from two banks (seven on the left bank and eight on the right) in August (low-water event) in 2018 in the section whose morphology was analyzed. At each sampling site, a sediment sample (approximately 200 g) was taken near the foot and top of the bank. The same approach was used for the Petite Nation River, where samples were taken from ten sites (five on the left bank and five on the right). The average distance between two sampling sites was approximately $2 \mathrm{~km}$ for the Matawin River and $1 \mathrm{~km}$ for the Petite Nation River. The sediment collected in the field was oven-dried at $105^{\circ} \mathrm{C}$ for two days, then sieved in the lab in a bank of wire mesh sieves. After sieving, sediments were divided into three granulometric classes: sand, silt and clay.

\section{Results}

\subsection{Comparison of magnitude and duration-frequency of flood indices between the two rivers}

Flow magnitude values for the two flood indices calculated in the two watersheds are indicated in Table 2. Figure 2 compares the interannual variability of mean annual maximum daily flows (Qmax) measured in the two watersheds. This table shows that the magnitude of annual flooding flows (Qmax) for the Matawin River is higher than for the Petite Nation River. The magnitude is on average about two times 
higher in the Matawin River watershed than in the Petite Nation River watershed. For the Q90 flood index, the flow magnitude means for the two rivers were not significantly different (figure 3 ). It is nevertheless important to note that the maximum and minimum values for this index are higher in the Matawin River watershed than in the Petite Nation River watershed.

Table 2

Comparison of magnitude $\left(\mathrm{l} / \mathrm{s} / \mathrm{km}^{2}\right)$ and duration-frequency (days) of two flood indices Qmax (high intensity flood) and Q90 (low intensity flood) for the Matawin and Petite Nation rivers (1945-2019)

\begin{tabular}{|c|c|c|c|}
\hline Flood indices & Variables & Matawin River & Petite Nation River \\
\hline \multicolumn{4}{|c|}{ Magnitude (I/s/km²) } \\
\hline \multirow[t]{3}{*}{$\geq$ Qmax } & mean & 107.4 (32.42)* & $65.7(23.53) *$ \\
\hline & $\max$ & 195 & 160.2 \\
\hline & $\min$ & 46 & 21.7 \\
\hline \multirow[t]{3}{*}{$\geq$ Q90 (<Qmax) } & mean & $38.2(10.55)$ & $36(10.91)$ \\
\hline & $\max$ & 91.6 & 74.9 \\
\hline & $\min$ & 22.7 & 12.2 \\
\hline \multicolumn{4}{|c|}{ Frequency-Duration (days) } \\
\hline \multirow[t]{3}{*}{$\geq \mathrm{Qmax}$} & mean & $26.2(11.15) *$ & $75.9(33.15) *$ \\
\hline & $\max$ & 58 & 171 \\
\hline & $\min$ & 1 & 9 \\
\hline \multirow[t]{3}{*}{$\geq$ Q90 (<Qmax) } & mean & $55.1(27.00) *$ & $14.7(11.19) *$ \\
\hline & $\max$ & 135 & 59 \\
\hline & $\min$ & 13 & 2 \\
\hline
\end{tabular}

In terms of the frequency-duration flood index, unlike flow magnitude, annual flooding flows (Qmax) were, on average, about three times shorter in the Matawin River watershed (26 days) than in the Petite Nation River watershed (76 days) per year (figure 4). This trend was completely reversed for the durationfrequency of the Q90 index (low and medium floods). For the Q90 index, flow duration-frequency was greater in the Matawin watershed ( 55 days) than in the Petite Nation watershed (15 days).

Figure 5 shows a concrete example of the very typical variation in daily flows (expressed in $\mathrm{l} / \mathrm{s} / \mathrm{km}^{2}$ ) during the 2018. It clearly shows that the Petite Nation River daily flows hydrograph is flatter than that of the Matawin River daily flows hydrograph. In addition, it also shows that the difference in the flows magnitude and duration between the two rivers are higher for the freshet (Qmax) in spring than those for 
rain-induced floods (Q90) in summer and fall. As such, during freshets, flows increase and decrease more slowly in the Petite Nation River than in the Matawin River, which explains why freshets in the first river are smaller in magnitude but higher in duration than in the second. It is important to note that freshet (Qmax) have a much greater morphological impact than those of summer-fall floods (Q90).

\subsection{Comparison of the characteristics of bankfull width and sinuosity of the two rivers}

Granulometric analysis of bank sediment are presented in Table 3. Both river banks (excluding rocky or pebble outcrop sections) consist mainly of fine sand. This clearly demonstrates that the lithological characteristics are identical in both watersheds given that they belong to the same geological formation (Canadian Shield).

Table 3

Comparison of the particle size characteristics of the sediment on the banks of the Matawin and Petite Nation Rivers

\begin{tabular}{|lllllll|}
\hline \multicolumn{3}{|c}{ Matawin River } & \multicolumn{5}{c|}{ Petite Nation River } \\
\hline & Sand (\%) & Silt (\%) & Clay (\%) & Sand (\%) & Silt (\%) & Clay (\%) \\
\hline Mean & 96.3 & 3.1 & 0.56 & 96.4 & 3.2 & 0.61 \\
\hline SD & 1.73 & 1.26 & 0.47 & 1.41 & 1.37 & 0.24 \\
\hline Max & 98.8 & 6 & 1.8 & 98.5 & 5.9 & 1.0 \\
\hline Min & 92.7 & 1.1 & 0 & 93.7 & 1.4 & 0.1 \\
\hline N = Number of samples; SD = standard deviation & & \\
\hline
\end{tabular}

Bankfull width and sinuosity values for the two rivers are presented in Table 4 and figure 6 . The mean bankfull width of the Petite Nation River was about twice the mean bankfull width and figure of the Matawin River, despite the fact that the area of the Matawin River watershed at the flow gauging station was slightly greater than the watershed area of the Petite Nation River. The Petite Nation River bankfull width (Wmax) highest value was still about four times higher than the Matawin River bankfull width value. However, this difference was relatively smaller for the minimum bankfull width value. The Matawin River channel is much more sinuous than the Petite Nation River channel. It follows that, morphologically, the Matawin River channel is narrower and more sinuous than the Petite Nation River, despite the fact that the Matawin River watershed is a little larger than the Petite Nation River watershed. 
Table 4

Comparison of bankfull width (W) and sinuosity values for the Petite Nation and Matawin rivers.

\begin{tabular}{|c|c|c|c|c|}
\hline \multirow[t]{2}{*}{ Variables } & \multicolumn{2}{|c|}{$\begin{array}{l}\text { Matawin River } \\
\left(1390 \mathrm{~km}^{2}\right)\end{array}$} & \multicolumn{2}{|c|}{$\begin{array}{l}\text { Petite Nation River } \\
\left(1330 \mathrm{~km}^{2}\right)\end{array}$} \\
\hline & $\mathrm{m}$ & $\mathrm{mm} / \mathrm{km}^{2}$ & $\mathrm{~m}$ & $\mathrm{~mm} / \mathrm{km}^{2}$ \\
\hline $\mathrm{N}$ & 264 & & 137 & \\
\hline Wmax & 67.4 & 48.5 & 295.8 & 222.4 \\
\hline Wmin & 21.2 & 15.3 & 33.6 & 25.2 \\
\hline Wmean & $44.8^{*}$ & $32.2^{*}$ & $97.1 *$ & $73 *$ \\
\hline Wmedian & 43.3 & 31.2 & 75.2 & 56.5 \\
\hline SD & 7.32 & 5.27 & 65.03 & 48.89 \\
\hline Sinuosity & 2.70 & & 1.47 & \\
\hline
\end{tabular}

\section{Discussion}

The two watersheds that were analyzed have very similar physiographic and climatic characteristics. This similarity helped determine how wetlands influence flood indices and the Petite Nation River channel morphology. In fact, the primary difference between the two watersheds is wetland and forest area. The area of wetlands is twice as large in the Matawin River watershed (15\%) as in the Petite Nation River watershed (9\%). Comparing the flow magnitude for the two flood indices (Qmax and Q90) for both rivers revealed a significant difference in the annual flooding flow magnitude (Qmax) between the two rivers. The magnitude of heavy floods (Qmax) was on average about two times higher in the Matawin River watershed than in the Petite Nation River watershed. The means of the flow magnitude for low and medium floods (Q90) of both rivers was not significantly different. As for the duration-frequency of flows, heavy floods, associated with annual flooding (Qmax), lasted less time (about three times less on average) in the Matawin River watershed than in the Petite Nation watershed. In contrast, low and medium intensity (magnitude) floods lasted less time in the Petite Nation watershed than in the Matawin River watershed. From a hydrological point of view, heavy floods associated with annual flooding (Qmax) are generated exclusively by spring snowmelt in both watersheds. In contrast, low and medium intensity floods, associated with the Q90 index, are mainly generated by rain in summer and autumn. However, they also include flows from snowmelt but lower (< Qmax) than the discharge from the annual flood. A recent study of the frequency of these rainfall floods found that the frequency was much lower in the Petite Nation River watershed than the Matawin River watershed due to the "sponge effect" of wetlands in the Petite Nation watershed (Assani, 2020, unpublished work). This sponge effect means that the wetlands absorb more runoff, preventing it from transferring directly to the channel (e.g., Acreman \& 
Holden, 2003; Bullock \& Acreman, 2003). This results in a more significant decrease in the occurrence of low and medium summer and fall floods in the Petite Nation River watershed than in the Matawin River watershed. The sponge effect of the wetlands also explains the significant decrease in the flow magnitude of annual flooding (Qmax) in the Petite Nation River watershed. These wetlands temporarily store snowmelt, reducing the intensity of spring flood peaks. Water that is temporarily stored in these wetlands is released into the river gradually, increasing the duration of the annual flooding (see figure 6).

Finally, the difference in forest cover between the two watersheds does not seem to influence either the magnitude or the duration-frequency of flooding. The decrease in forest cover in the Petite Nation River watershed is expected to result in an increase in flow magnitude (not a decrease) for the annual flooding as observed in the agricultural watershed of the L'Assomption River, adjacent to these two watersheds (Sylvain et al., 2015), due to increased surface runoff. Nevertheless, the L'Assomption River's agricultural watershed features impermeable soil that promotes runoff, unlike in the Petite Nation River watershed. When the snow melts in spring, the decrease in forest cover accelerates the snowmelt, which leads to a rapid increase in flows but a decrease in their duration. This hydrological behaviour is completely different from that of the Petite Nation River watershed, which has a smaller forest area (83\%) than the Matawin River watershed (90\%).

Morphologically, the longer duration-frequency of heavy flood flows (Qmax) in the Petite Nation River watershed led to a relatively large widening of the river channel, despite the fact that the magnitude was much smaller than the magnitude observed in the Matawin River. As a result, the mean bankfull width of the Petite Nation River has become at least twice the Matawin River's mean bankfull width. The longer duration of heavy flood flows favours the intersection of meanders, reducing channel sinuosity. The Matawin River channel is therefore narrower and less sinuous than the Petite Nation River channel. The lithological context is the same in the two watersheds, which are located on the Canadian Shield, so this morphological difference cannot be explained by sedimentological and geological factors.

In addition to these freshet flow characteristics, the role of the amount of sediment (suspended load carried by both rivers) must not be ignored. Temporary storage of runoff in wetlands also promotes the sedimentation of suspended particles in runoff. This significantly reduces the amount of sediment carried by runoff to the channels. A small suspended load promotes shoreline erosion (channel widening) as has been shown in watersheds whose suspended loads have gone down significantly since reforestation (e.g., Assani et al., 2003; 2017) overtook agricultural activities in watersheds, which is consistent with Schumm's formula (1969).

\section{Conclusion}

Land use plays a crucial role in flood dynamics and changes in channel morphology. Comparing the impacts of different land use between the Petite Nation and Matawin watersheds made it possible to determine the hydromorphological impacts induced by the difference in wetland area. In the Petite Nation River watershed, which has a larger wetland area (15\%) than the Matawin River watershed (9\%), the 
magnitude of heavy flows associated with the annual flooding (Qmax) was almost two times lower than the magnitude observed in the Matawin River watershed. In contrast, the duration-frequency of these flows was on average about three times higher than the duration-frequency of Matawin River flows. The decrease in flow magnitude associated with an increase in duration-frequency was the result of the wetlands' sponge effect on the runoff and infiltration process of the hydrological cycle. Morphologically, the hydrological behaviour induced by wetlands resulted in a widening and decreased sinuosity of the Petite Nation River. The difference in forest area between the two watersheds had no noticeable impact on the characteristics of heavy flood flows and channel morphology, highlighting the predominant role of wetlands in the hydromorphological evolution of Canadian Shield watercourses in Quebec. In terms of flooding, this role translates as a significant reduction in intensity, the environmental effects of which clearly appear to be hindered by their relatively long duration.

\section{Declarations}

Conflict of Interest: No conficts of interest are declared.

Ethics Approval: Not applicable.

Consent to Participate: Not applicable.

Consent for Publication: Not applicable

Data availability: The author may provide the data used in the manuscript upon request.

Funding: This work was supported by the Natural and Engineering Science Research Council of Canada (Grant $\left.n^{\circ}: 261274 / 2019\right)$.

\section{References}

1. Acreman MC, Holden J (2013) How wetlands affect floods. Wetlands 33:773-786

2. Anctil F, Martel F, Hoang VD (1998) Analyse régionale des crues journalières de la province du Québec. Canadian Journal of Civil Engineering 25:125-146

3. Archer D (2003) Scale effects on the hydrological impact of upland afforestation and drainage using indices of flow variability: the River Irthing, England. Hydrology and earth System Sciences. 7: 325338

4. Assani AA, Quessy JF, Mesfioui M, Matteau M (2010) An example of applications: the ecological "natural flow regime" paradigm in hydroclimatology. Ad Water Res 33:537-545. doi:10.1016/j.adwatres.2010.02.005

5. Assani AA, Landry R, Kinnard C, Azouaoui O, Demers C, Lacasse K (2016) Comparison of the spatiotemporal variability of temperature, precipitation, and maximum daily spring flows in two 
watersheds in Quebec characterized by different land use. Adv Meteor 2016. doi: $10.1155 / 2016 / 3746460$

6. Assani AA, Chauvette L, Campeau S (2017). Analysis of the Impacts of Changes in Streamflow and of Restoration on the Morphological Evolution of the Matambin River Channel in the St. Lawrence Lowlands (Quebec, Canada), Hydro-Geomorphology - Models and Trends, Shukla DP, IntechOpen, DOI: 10.5772/intechopen.68444. Available from: https://www.intechopen.com/chapters/54918

7. Assani AA, Petit F, Buffin-Bélanger T, Roy AG (2003) Analyse de la variation spatio-temporelle de la morphologie du chenal de la Warche en amont du barrage de Bütgenbach (Belgique). Zeit Geomorphol 47:469-483. DOI:10.1127/zgf/47/2003/469

8. Aubry L, Assani AA, Biron S, Gratton D (2013) Comparison of the hydromorphological evolution of the L'Assomption and Ouareau river channels (Quebec, Canada). River Res Applic 29:979-990. doi:10.1002/rra.2584

9. Baillie BR, Davies TR (2002) Effects of land use on the channel morphology of streams in the Moutere gravels, Nelson, New Zealand. J Hydrol, New Zealand. 41: 19-45

10. Bandyopadhyay S, De SK (2018) Anthropogenic impacts on the morphology of the Haora River, Tripura, India. Géomorphol: relief, processus, environnement. 24: 151-166, doi: 10.4000/geomorphologie.12019

11. Belzile L, Bérubé P, Hoang VD, Leclerc M (1997) Méthode écohydrologique de détermination des débits réservés pour la protection des habitats du poisson dans les rivières du Québec. Rapport présenté par l'INRS-Eau et le Groupe-conseil Génivar inc. au ministère de l'Environnement et de la Faune et à Pêches et Océans Canada. 83 p. +8 annexes

12. Blöschl G, Ardoin-Bardin S, Bonell M, Dorninger M, Goodrish D, Gutknecht D, Matamoros D, Metz B, Shand P, Szolgay J (2007) At what scales do climate variability and land cover change impact on flooding and low flows? Hydrol Process. 21: 1241-1247, doi: 10.1002/hyp.6669

13. Booth DB, Blesdoe BP (2009) Stream and urbanization. In Baker LA (ed): The water environment of cities, Springer Science, doi: 10.1007/976-0-84891-4_6

14. Brandolin P, Avalos MA, De Angelo C (2013) The impact of flood on the loss of wetlands in Argentina. Aquat Conserv Mar Freshwat Ecosyst 23:291-300. doi:10.1002/aqc.2305

15. Branfireun B, Roulet NT (1998) The baseflow and storm flow hydrology of a Precambrian shield headwater peatland. Hydrol Process 12:57-72

16. Bronstert A, Niehoff D, Bürger G (2002) Effects of climate and land-use change on storm runoff generation: present knowledge and modelling capabilities. Hydrol Process 16:509-529

17. Brown AE, Zhang L, McMahon TA, Western AW, Vertessy RA (2005) A review of paired catchment studies for determining changes in water yield resulting from alterations in vegetation. J Hydrol 310:28-61. doi:10.1016/j.jhydrol.2004.12.010

18. Bullock A, Acreman MC (2003) The role of wetlands in the hydrological cycle. Hydrol Earth Syst Sci 7:358-389 
19. Buytaert W, De Bièvre B, Wyseure G, Deckers J (2004) The use of the linear reservoir concept to quantify the impact of changes in land use on the hydrology of catchments in the Andes. Hydrol Earth Syst Sci 8:108-114

20. Caissie D, Jolicoeur S, Bouchard M, Poncet E (2002) Comparison of streamflow between pre and post timber haversting in Catamaran Brook (Canada). J Hydrol 258:232-248

21. Clark JJ, Wilcock PR (2000) Effects of land-use change on channel morphology in northeast Puerto Rico. Geol Soc Amer Bull 112:15

22. Cooper SD, Lake PS, Sabater S, Melack JM, Sabo JL (2013) The effects of land use change on streams and rivers in Mediterranean climates. Hydrobiol 9:384-425. doi:10.1007/s10750-012-13334

23. Devito KJ, Hill AR, Roulet N (1996) Groundwater-surface water interactions in headwater forested wetlands of the Canadian Shield. J Hydrol 181:127-147

24. Fashae OA, Olusola AO (2017) Landuse types within channel corridor and river channel morphology of river Ona, Ibadan, Nigeria. Indonesia J Geogr 49:111-117. Doi:10.22146/ijg.12738

25. Ferguson RI (1986) Hydraulics and hydraulic geometry. Progr Phys Geogr 10:1-31

26. Fraser CJD, Roulet NT, Lafleur M (2001) Groundwater flow patterns in a large peatland. Journal of Hydrology 246:142-154

27. Gordon E, Meentemeyer RK (2006) Effects of dam operation and land use on stream channel morphology and riparian vegetation. Geomorphol 82:412-429. doi:10.1016/j.geomorph.2006.06.001

28. Haddeland I, Skaugen T, Lettenmaier DP (2007) Hydrologic effects of land and water management in North America and Asia: 1700-1992. Hydrol Earth Syst Sci 11:1035-1045

29. Kasai M (2006) Channel processes following land use changes in a degrading steep headwater stream in North Island, New Zealand. Geomorph 81:421-439. doi:10.1016/j.geomorph.2005.11.014

30. Lane PNJ, Best AE, Hickel K, Zhang L (2005) The response of flow duration curves to afforestation. Journal of Hydrology 310:253-265. doi:10.1016/j.jhydrol.2005.01.006

31. Lavigne M-P, Rousseau A, Turcotte R, Laroche A-M, Fortin J-P, Villeuve J-P (2004) Validation and use of semidistributed hydrological modeling system to predict short-term effects of clear-cutting on a watershed hydrological rehime. Earth Interact 1:1-19

32. Li KY, Coe MT, Ramankutty N, De Jong R (2007) Modeling the hydrological impact of land-use change in west Africa. J Hydrol 337:258-268. doi:10.1016/j.jhydrol.2007.01.038

33. Lu XX (2005) Spatial variability and temporal change of water discharge and sediment flux in the lower Jinsha tributary: impact of environmental change. River Res Applic 21:229-243. doi:10.1002/rra.843

34. Muma M, Assani AA, Landry R, Quessy JF, Mesfioui M (2011) Effects of the change from forest to agriculture land use on the spatial variability of summer extreme daily flow charactersitics in southern Quebec (Canada). J Hydrol 407:153-163. doi:10.1016/j.jhydrol.2011.07.020 
35. Muma M, Rousseau AN, Gumiere SJ (2016) Assessment of the impact of subsurface agricultural drainage on soil water storage and flows of a small watershed. Water 8:326. doi:10.3390/w8080326

36. Nabegu AB (2014) Impact of urbanization on channel morphology: some comments. J Environ Sci Tox Food Techn 8:40-45

37. O'Connell E, Ewen J, O'Donnell G, Quinn P (2007) Is there a link between agricultural land-use management and flooding? Hydrol Earth Syst Sci 11:96-107

38. Ott B, Uhlenbrook S (2004) Quantifying the impact of land-use changes at the event and seasonal time scale using a process-oriented catchment model. Hydrol Earth Syst Sci 8:62-78

39. Petersen CR, Jovanovic DC, Grenfell MC (2017) Effects of land use change on streamflow and stream water quality of a coastal catchment. Water SA 43:139-152

40. Pfister L, Kwadik J, Musy A, Bronstert A, Hoffmann L (2004) Climate change, land use change and runoff prediction in the Rhine-Meuse basins. River Res Applic 20:229-241. doi:10.1002/rra.775

41. Poff NL, Allan JD, Bain MB, Karr JR, Prestegaard KL, Richter BD et al (1997) The natural

42. flow regime. A paradigm for river conservation and restoration. Bioscience. 47: 769-784

43. Poff NL, Blesdoe BP, Cuhaciyan CO (2006) Hydrologic variation with land use across the contiguous United States: geomorphic and ecological consequences for stream ecosystems. Gemorphol 79:264-285. Doi:10.101016/j.geomorph.2006.06.032

44. Quilbé R, Rousseau A, Moquet J-S, Savary S, Ricard S, Garbouj MS (2008) Hydrological response of a watershed to historical land use evolution and future land use scenarios under climate change conditions. Hydrol Earth Syst Sci 12:101-110

45. Quinto WL, Roulet NT (1998) Spring and summer runoff hydrology of a subarctic patterned wetland. Arc Alp Res 30:285-294

46. Robinson M, Dupeyrat A (2005) Effects of commercial haversting on streamflow regimes in the Plynlimon catchments, mi-Wales. Hydrol Process 19:1213-1226. doi:10.1002/hyp.5561

47. (van) Roosmalen L, Sonnenborg TO, Jensen KH (2009) Impact of climate and land use change on the hydrology of a large-scale agricultural catchment. Water Res Res. 45: W00A15, doi: 10.1029/2007WR006760

48. Roulet NT (1990a) Hydrology of headwater basin wetland: Groundwater discharge and wetland maintenance. Hydrol Process 4:387-400

49. Roulet NT (1990b) Focus: aspects of the physical geography of wetlands. The Can Geogr 34:79-88

50. Roulet NT (1991) Stormflow production in a headwater basin swamp. Nord Hydrol 22:161-174

51. Roulet NT, Woo M-K (1998) Low Artic wetland hydrology. Can Water Res J 11:69-75. doi:10.4296/cwrj1101069

52. Shepherd SL, Dixon JC, Davis RK, Feinstein R (2010) The effects of land use on channel geometry and sediment distribution in gravel mantled bedrock streams, Illinois River watershed, Arkansas. River Res Applic 27:857-866. doi:10.1002/rra.1401 
53. Storck P, Bowling L, Wetherbee P, Lettenmaier D (1998) Application of a GIS-based distributed hydrology model for prediction of forest haverst effects on peak stream flow in the Pacific Northwest. Hydrol Process 12:889-904

54. Schumm SA (1969) River metamorphosis. Journal of Hydraulics Division. Proc Amer Soc Civ Eng HY1:255-273

55. Sylvain JM, Assani AA, Landry R, Quessy JF, Kinnard C (2015) Comparison of the spatio-temporal variability of annual minimum daily extreme flow characteristics as a function of land use and dam management mode in Quebec,Canada. Water 7:1232-1245

56. Tan X, Gan TY (2015) Contribution of human and climate change impacts to changes in streamflow of Canada. Nature Scientific Reports 5:17767. doi:10.1038/srp17767

57. Townsend CR, Downes BJ, Peacock K, Arbuckle CJ (2004) Scale and the detection of land-use effects on morphology, vegetation and macroinvertebrate communities of grassland streams. Freshw Biol 49:448-462

58. Vadnais ME, Assani AA, Landry R, Leroux D, Gratton D (2012) Analysis of the effects of human activities on the hydromorphological evolution channel of the Saint-Maurice River downstream from La gabelle dam (Quebec, Canada). Geomorphol 175-176:199-208

59. Vanacker V, Molina A, Govers G, Poesen J, Dercon G, Deckers S (2005) River channel response to short-term human-induced change in landscape connectivity in Andean ecosystems. Gemorphol 72:340-353

60. Wang D, Hejazi M (2011) Quantifying the relative contribution of the climate and direct human impacts on mean annual streamflow in the contiguous United States. Water Resourc Res. 47: W00J12, doi: 10.1029/2011WR010283

61. Yan R, Cai Y, Li C, Wang X, Liu Q (2019) Hydrological response to climate and land use changes in a watershed of the Loess Plateau, China. Sustainability 11:1443. doi:10.3390/su11051443

62. Zeiger SJ, Hubbart JA (2019) Characterizing land use impacts on channel geomorphology and streambed sedimentological characteristics. Water 11:1088. doi:10.3390/w11051088

63. Zhang L, Cheng L, Chiew F, Fu B (2018) Understanding the impacts of climate and landuse change on water yield. Curr Op Environ Sustain 33:167-174. doi:10.1016/j.cosust.2018.04.017

\section{Figures}




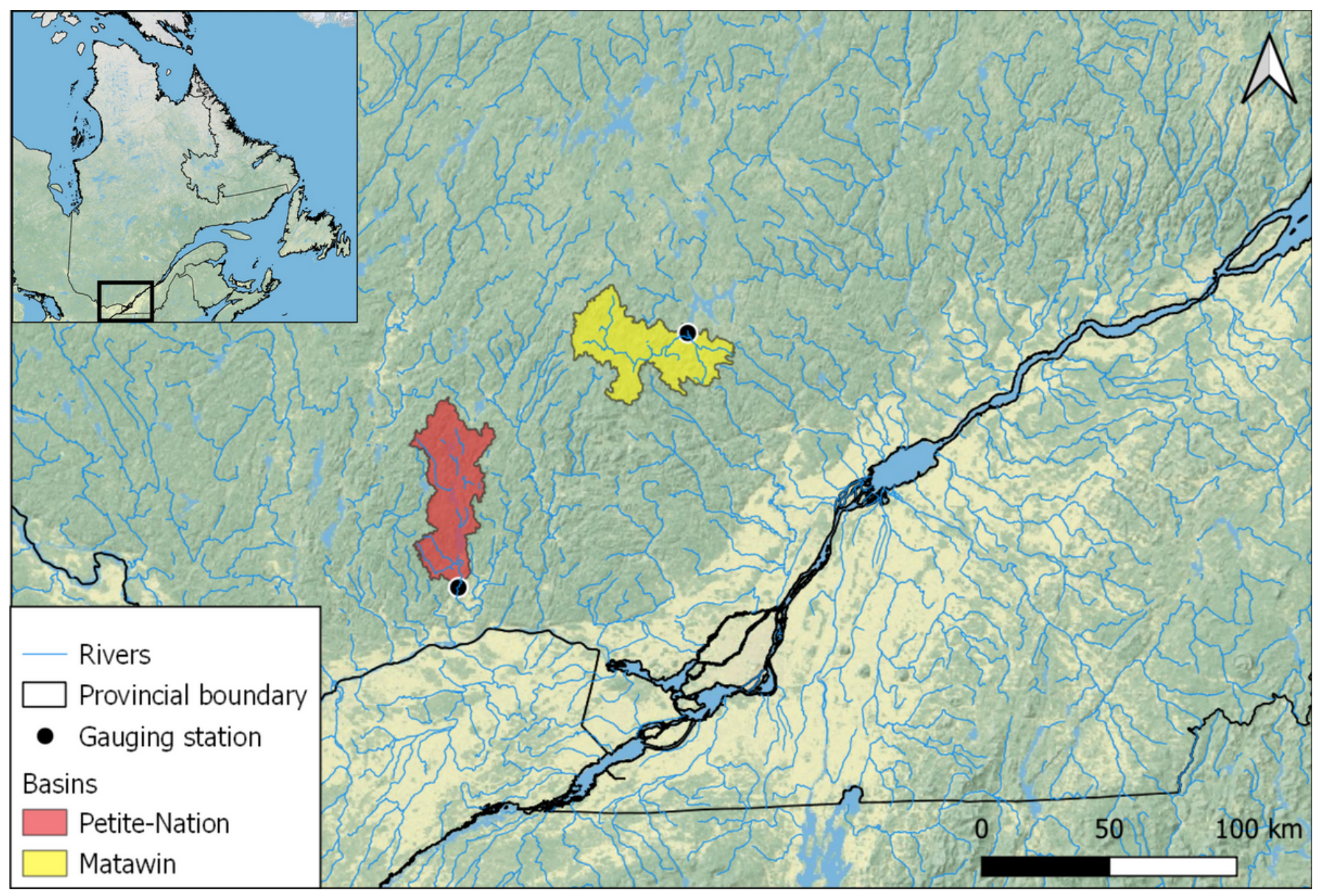

Figure 1

Locations of the two watersheds 


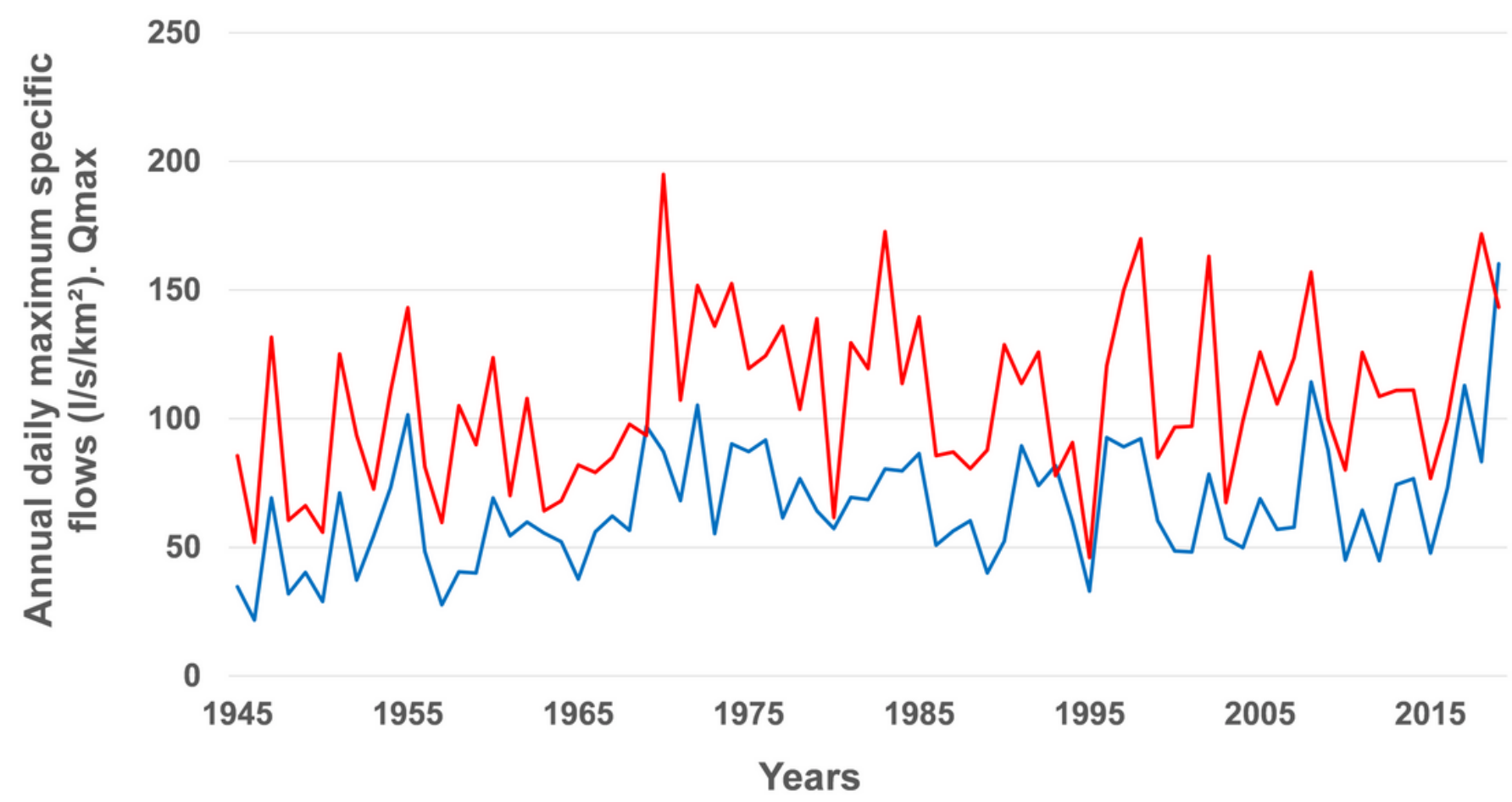

Figure 2

Comparison of the interannual variability of annual maximum daily flows (Qmax flood index) for the Matawin (red line) and Petite Nation (blue line) rivers from 1945-2019

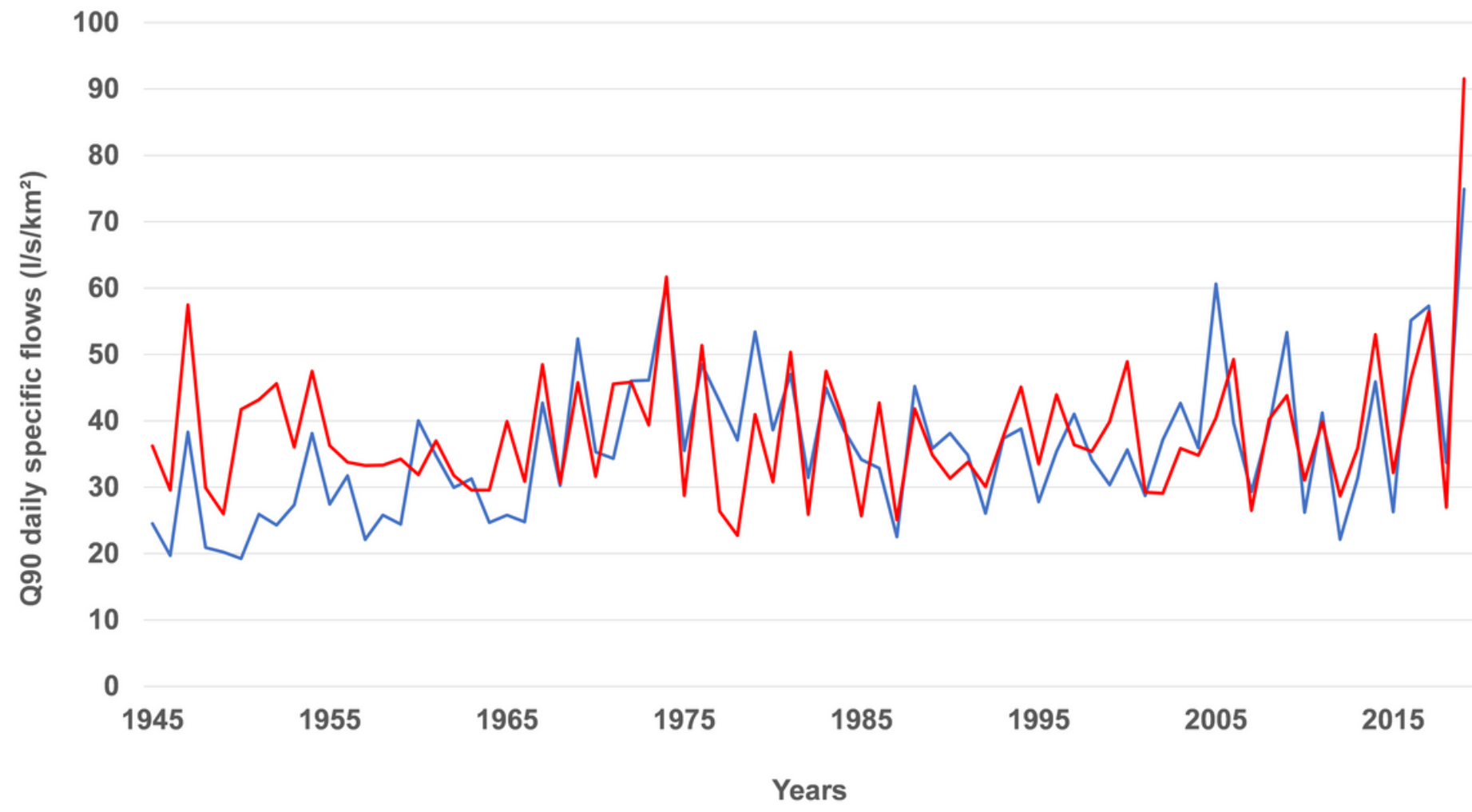


Figure 3

Comparison of the interannual variability of daily flows corresponding to the 90th percentile (Q90 flood index) for the Matawin (red line) and Petite Nation (blue line) rivers from 1945-2019

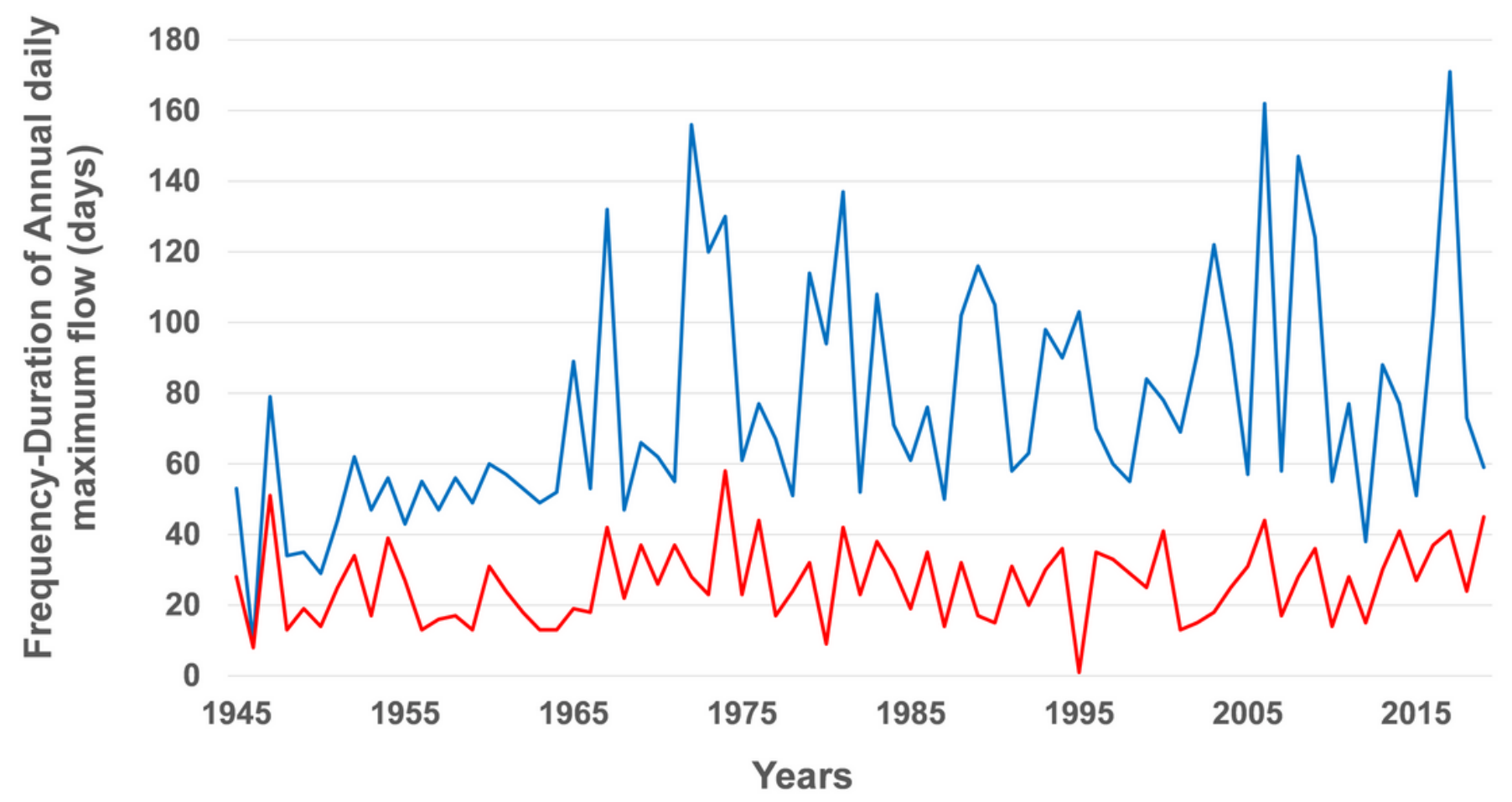

Figure 4

Comparison of the interannual variability of annual maximum daily flows duration (Qmax flood index) for the Matawin (red line) and Petite Nation (blue line) rivers from 1945-2019 


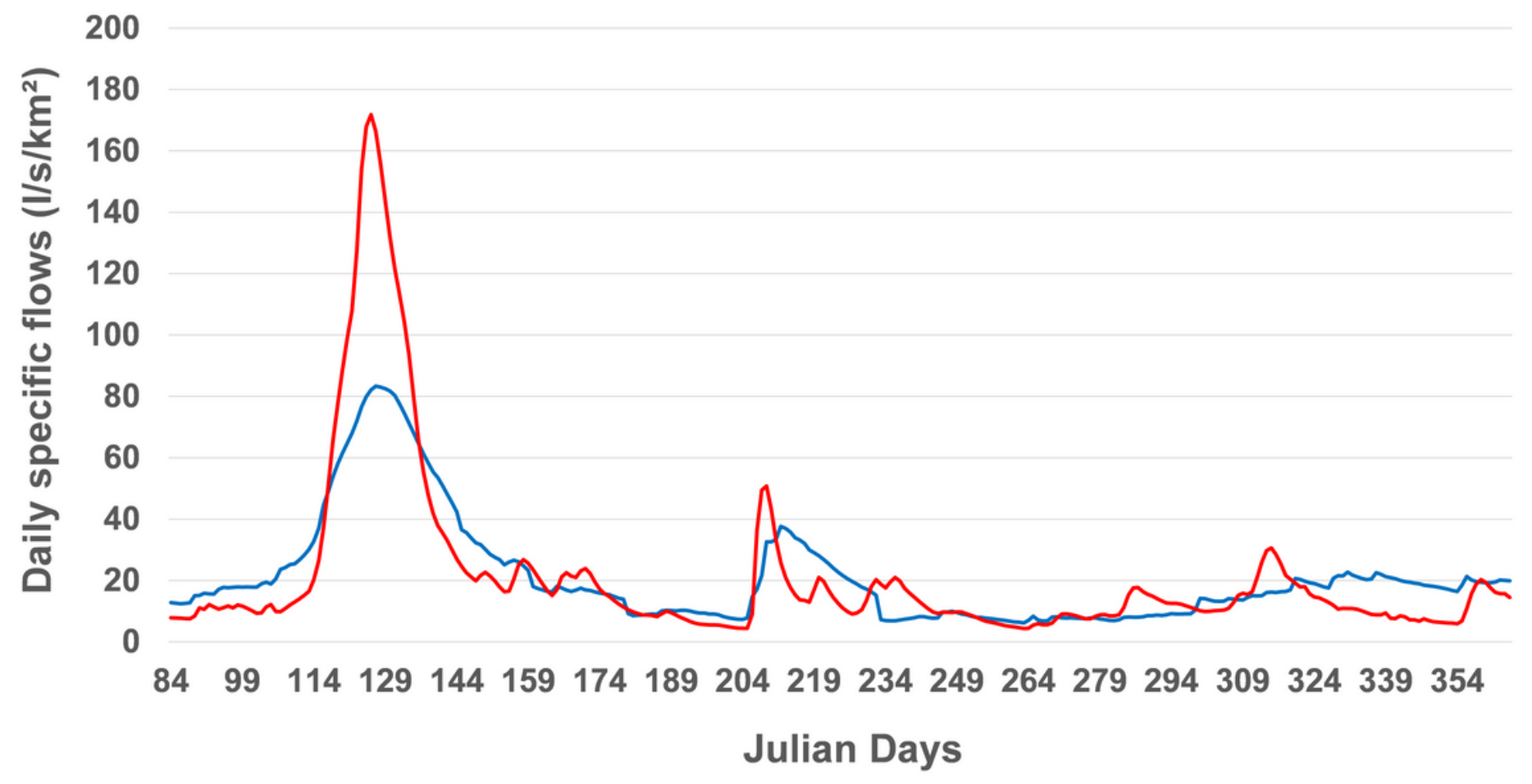

Figure 5

Example of daily specific flows hydrographs for two rivers in 2018: Matawin (red curve) and Petite Nation (blue curve) Rivers. This figure clearly shows that the hydrographs of the Petite Nation River is more flattened than that of the Matawin River.

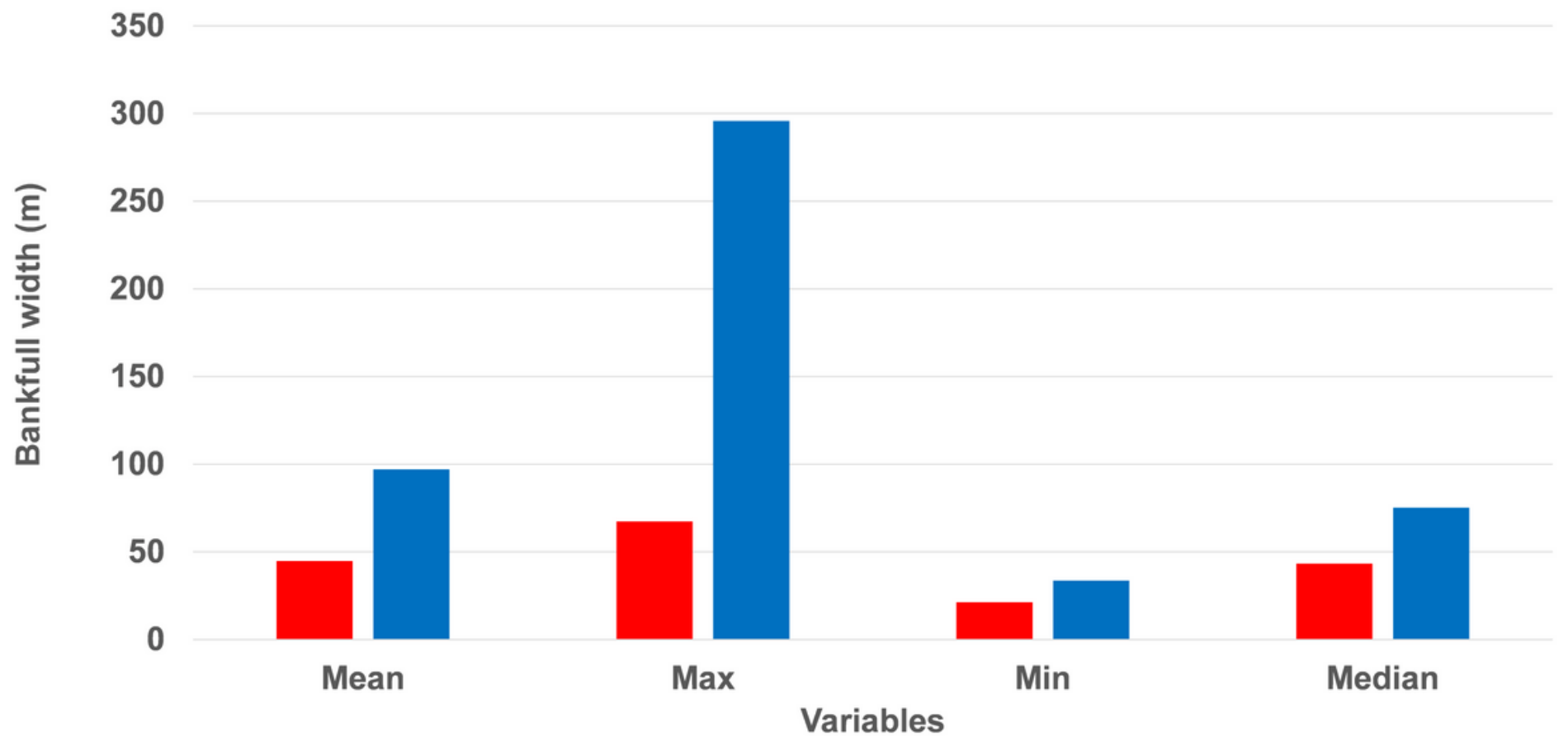

Figure 6 
Comparison of bankfull width values for the Matawin (red line) and Petite Nation (blue line) rivers. 